\title{
Financial Sector Innovation and Economic Growth in the Context of Botswana
}

\author{
Johane Moilwa Motsatsi ${ }^{1}$ \\ ${ }^{1}$ Botswana Institute for Development Policy Analysis, Botswana \\ Correspondence: Johane Moilwa Motsatsi, Botswana Institute for Development Policy Analysis, Botswana. Tel: \\ 267-361-7757. E-mail: jmmotsatsi@bidpa.bw
}

Received: January 19, 2016

Accepted: February 24, 2016

Online Published: May 25, 2016

doi:10.5539/ijef.v8n6p291

URL: http://dx.doi.org/10.5539/ijef.v8n6p291

\begin{abstract}
The objective of this study is to examine the role of financial sector development on economic growth using quarterly time series data for the period 2006-2014. We used Autoregressive Distributed Lag (ARDL) model to estimate the impact of technological innovation (Automated Teller Machines \{ATMs\} and Electronic Funds Transfer at Point of Sale\{EFTPOS $\}$ ), business innovation (bank deposits and credit to private sector) and other determinants of economic growth (inflation, trade and interest rate) on economic growth. The results show that both the technological and business innovation variables have a positive impact on economic growth. Therefore, policies aimed at promoting more distribution and nationwide spread of ATMs and EFTPOS more particularly in rural areas where they are scarce would boost the growth of the economy. In addition, The Global Competitiveness Report (GCR) asserted that Botswana's financial market is still undeveloped and fall short to the development level of middle income countries. GCR identified the quality of the education system as the main factor dragging the development of the financial sector down. It is focused more on academic achievement rather than equipping learners with practical skills and work experience that can support the national innovative initiatives.
\end{abstract}

Keywords: financial innovation, economic growth, technological and business innovation

\section{Introduction}

The role of financial sector innovation on economic growth in Botswana has received little attention. The purpose of this study is to fill this gap. The assessment of the role of financial sector innovation on economic growth is important because it assesses the progress made and discusses emerging gaps with the view of identifying areas of improvement. The study specifically estimates the role of bank's technological innovation on economic growth such as Electronic Funds Transfer at Point of Sale (EFTPOS) and Automated Teller Machines (ATMs) as the first type of financial sector development. The second type of financial sector development is business innovation (credit channeled to the private sector and bank's total deposits). We also used major determinants of economic growth such as international trade, interest rate and inflation rate.

The existence of technological innovation such as EFTPOS and ATMs is beneficial to economic agents because they provide payment systems that are cost effective and efficient in delivering bank services to customers (Ogbuji, Onuoha, \& Izogo, 2012). With increased availability of ATMs, it would be less time consuming to request bank account statement, withdraw or deposit cash at an ATM rather than visiting the bank in person. For this reason, banks are likely to cut their labor costs as less manpower would be required to carry out day to day bank teller activities (Markose \& Loke, 2003). On the other hand, availability of EFTPOS has brought the emergence of alternative means of payments (non cash payments). These payment systems are less costly when compared to cash. Therefore, they would facilitate the consumption of goods and services domestically and internationally. Therefore, promoting innovation in bank technology would facilitate household spending and trade of goods and services (Kumanga, 2010; Hasan, Reinzi, \& Schmiedel, 2012).

In addition, financial innovation or development is important for promoting the bank's operations to be more efficient and productive. Following Hasan, Renzi, and Schmiedel (2013), bank's business innovation encourages allocation of available resources to more productive use for investment purposes through management of risks. That is, banks would allocate their recourse to less risky investment opportunities which have the potential to yield high returns in the future. Banks would also encourage savings by introducing positive deposit interest 
rates which would further support investment activities. Since investment, household consumption and trade are the key components of Gross Domestic Product (GDP), their increment would also drive up economic growth.

Financial sector innovation in terms of technology is generally essential for the development of the financial sector and subsequently the economy as a whole. That is because it promotes the efficiency and productivity of the banking sector through less operating costs and quick delivery of services. It also encourages competition among financial institutions in terms of providing financial services to the public such as capital for investment, and offer low lending rates in order to prop-up household consumption and investment, which as a result influence increased growth of the economy.

However, the Global Competitiveness Reports (GCR) indicates that Botswana's financial sector is still not well developed and fall short of a development level of other countries around the world. Table 1 below show that the 2011/12 GCR ranked Botswana $44^{\text {th }}$ and $101^{\text {st }}$ in terms of financial sector development and technological readiness, respectively. During 2012/13 and 2013/14, financial sector development ranking fell to $53^{\text {rd }}$ in both years, while its technological readiness was ranked $106^{\text {th }}$ and $104^{\text {th }}$ during $2012 / 13$ and $2013 / 14$, respectively. GCR highlighted that the country's biggest obstacle to improve its competitiveness rankings remain to be inadequately educated labor force. Despite the commitment made by the government for its considerable spending on education, there is still low rate of education enrolment at primary and secondary schools. The quality of high education system is also perceived not satisfactory with the requirements of the labor market.

Table 1. Botswana competitiveness rankings

\begin{tabular}{lllllllllll}
\hline Year & \multicolumn{2}{c}{$2009 / 10$} & & \multicolumn{2}{c}{$2010 / 11$} & \multicolumn{2}{c}{$2011 / 12$} & \multicolumn{2}{c}{$2012 / 13$} & \multicolumn{2}{c}{$2013 / 14$} \\
\hline Indicator & Rank & Score & Rank & Score & Rank & Score & Rank & Score & Rank & Score \\
FMD & 47 & 4.53 & 47 & 4.49 & 44 & 4.44 & 53 & 4.39 & 53 & 4.34 \\
TR & 92 & 3.16 & 99 & 3.13 & 101 & 3.12 & 106 & 3.17 & 104 & 3.11 \\
\hline
\end{tabular}

Source: Generated from GCR, WEF (2009/10-2013/14).

Note. FMD is Financial Market Development, TR is Technological Readiness.

However, over the last decade, the Botswana banking sector has experienced some significant improvement in terms of technological innovation in the form of EFTPOS and ATMs installation. This is evidenced by the decline in amount of currency circulating in the economy of Botswana, showing that EFTPOS and ATMs are increasingly replacing cash in terms of payments. As a share of broad money supply (M2), currency in circulation has declined almost by half, it declined from 9.4 percent in the second quarter of 2003 to 4.7 percent in the fourth quarter of 2012 (Figure E1 in Appendix). However, most of the innovation is still concentrated in urban areas (cities and major villages) which suggest that there is still room for improvement by installing more EFTPOS and ATMs in rural areas.

Therefore, the main objectives of this study are to:

i. Estimate the impacts of financial sector innovation on economic growth using Autoregressive Distributed Lag (ARDL) model.

ii. Assess progress made on financial sector development and discuss emerging gaps with view of identifying areas of improvement.

The remainder of the study is organized as follows. Section 2 provides a brief overview of development in payment systems and competitiveness of Botswana financial market. In Section 3, we provide a review of the literature and empirical findings related to the impacts of financial innovation on economic growth. Section 4 describes data and model specification used in the study, while Section 5 discusses the estimated results. Finally, Section 6 presents the concluding remarks and policy implications of the study.

\section{Financial Innovation and Competitiveness}

\subsection{EFTPOS and ATMs Transactions}

Prior to the introduction of non cash payments in Botswana, cash was the preferred and dominant payment system, and it has been increasingly replaced by non cash payments such as EFTPOS and ATMs. Figure 1 shows the trend of EFTPOS and ATMs based on thousands units of transactions (bar graph) and their growth rates (line graph) from 2006 to 2014. 


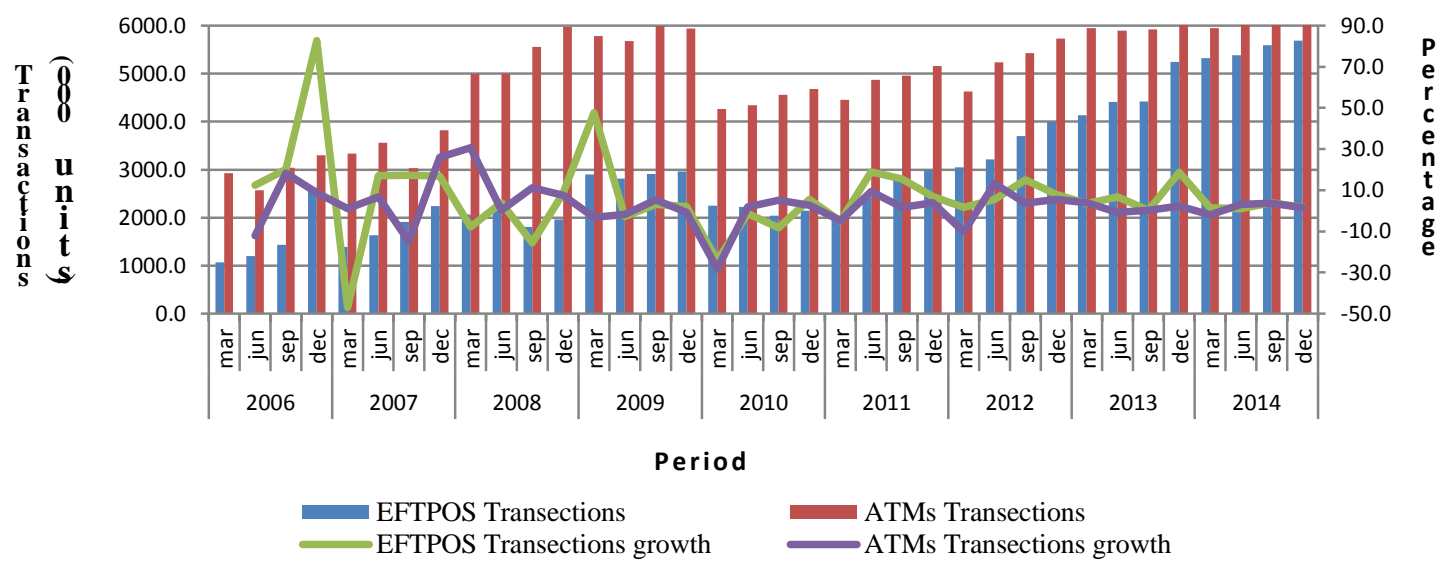

Figure 1. Units of EFTPOS and ATMs transactions

The units of ATMs transactions showed an upward trend from the first quarter of 2006 until the fourth quarter of 2008 , when its growth rate was estimated at 8.5 percent. Then it showed a downward trend for the first two quarters of 2009, went up in the third quarter and went down again in both the fourth quarter of 2009 and first quarter of 2010. From then, it showed an upward trend up until the fourth quarter of 2012, when its growth rate was estimated at 5.6 percent. In addition, unit of EFTPOS transactions was fluctuating from the first quarter of 2006 until the fourth quarter of 2010, when its growth rate was estimated at 5.4 percent. From the first quarter of 2011 is started to show an upward trend to the last quarter of 2012, when its growth rate stood at 8.0 percent.

Figure 2 shows values of EFTPOS and ATMs transactions in Million Pula and their growth rates. Values of ATMs transaction (in million Pula) were trending upward from the first quarter of 2006 to the fourth quarter of 2008 , when its growth rate stood at 11.0 percent. Its trend started to fluctuate slightly during 2009 , and then showed an upward trend from the first quarter of 2010 to the fourth quarter of 2011, when its growth rate was estimated at 6.5 percent. The trend dropped in the first quarter of 2012 and started trending upward until the fourth quarter of 2012, when its growth rate was estimated at 8.3 percent. On the other hand, values of EFTPOS (in million Pula) showed a slight upward trend from the first quarter of 2006 to the last quarter of 2009, when its growth rate stood at 2.3 percent. Then it started to show a downward trend until the first quarter of 2012, and started trending upward to the last quarter of 2012, when its growth rate was estimated at 13.4 percent.

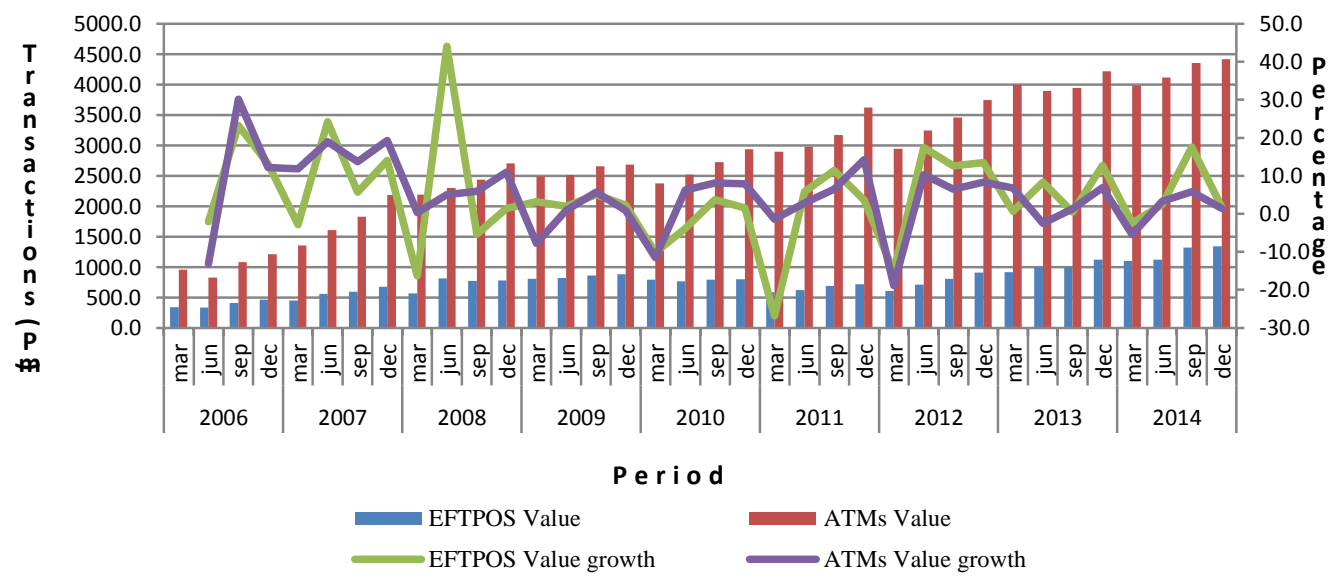

Figure 2. Values of EFTPOS and ATMs transactions

\subsection{Botswana Global Competitiveness Indicators}

Ranking Botswana among other countries around the world illustrates that the country's competitiveness indicators remain low by international standards. Table 2 below shows that 2012/13 and 2013/14 GCR ranked Botswana 93 and 91 for adopting the latest technology, respectively. Its capacity for innovation is also not 
competitive as compared to other countries, it was ranked 95 in 2012/13 GCR and worsened to 102 in 2013/14 GCR. The country's inability to invest in the latest technology and its limited capacity for innovation has also constrained the soundness of the banking sector to be competitive like the banking sector of other developing and developed countries. It was ranked 50 and 46 in 2012/13 GCR and 2013/14 GCR, respectively.

Botswana is also not competitive in providing the public with financial services. It was ranked 72 by 2012/13 GCR and 78 by 2013/14 GCR for availing financial services to the public. The quality of the education system is viewed as the main factor dragging the competitiveness of Botswana down. Despite the government high spending on education, there is still low rate of enrolment at primary and secondary schools. The quality of high education system is also inadequate to match the needs of the labor market, which focused more on academic achievement rather than practical skills that can support development initiatives in the country.

Its quality of high education system was ranked 58, 55 and 65 by 2011/12, 2012/13, and 2013/14 GCR, respectively. As identified by the GCR, deficiency in the development of Botswana's financial sector is due to low quality of the education system. As a result, this has led to poor improvements in soundness of banks, adoption of latest technology, capacity for innovation and availability of financial services to the public.

Table 2. Competitiveness indicators

\begin{tabular}{lcccc}
\hline Indicator & $\mathbf{2 0 1 0} / \mathbf{1 1}$ & $\mathbf{2 0 1 1} / \mathbf{1 2}$ & $\mathbf{2 0 1 2 / 1 3}$ & $\mathbf{2 0 1 3 / 1 4}$ \\
\hline Quality of high education system & 48 & 58 & 55 & 65 \\
Soundness of banks & 39 & 35 & 50 & 46 \\
Availability of latest technology & 78 & 84 & 93 & 91 \\
Capacity for innovation & 103 & 104 & 96 & 102 \\
Availability of financial services & 73 & 73 & 72 & 78 \\
\hline
\end{tabular}

Source: Global Competitiveness Report, WEF (2010/11-2013/14).

\section{Economic Theory and Empirical Findings}

\subsection{Brief Review of Economic Theory}

The existing literature reveal that financial innovation has a positive impact on financial development. It is often used to improve the performance of the financial sector and subsequently the growth of the whole economy. According to Abdul Jalil and Ying Ma (2008), financial sector development promotes the soundness and well functioning of the financial sector. It encourages increased rate of savings through positive rate of interest which enable more availability of funds for investment activities. When funds from savings are used more effectively for productive investment, it will lead to improved growth of the economy.

Ho (2006) asserted that financial sector innovation facilitates the consumption and trade of goods and services. Modernizing the financial sector through technological innovation provides payment systems that are less costly and easier when compared to cash payment and consequently promote the consumption of goods and services domestically as well as internationally. It also better organizes the structure of financial institutions in such a way that it reduces its operating costs and encourages quick and efficient delivery of services to customers.

Carbo, Paso, and Rodriguez (2004) carried a study on the role of financial innovation on economic growth. They indicated that financial sector development helps to manage risks by allocating savings to more productive investment and ignore less productive investment activities. However, the role of financial sector innovation or development on economic growth depends on the level of financial sector development. Its impact on economic growth is more with well developed financial sector and less with undeveloped financial sector.

Hasan, Renzi, and Schmiedel (2013) also emphasized that technological innovation enables the financial sector to provide payments systems that are efficient in delivering services to customers. As a result, these innovations are important in promoting the performance and efficiency of financial institutions, availability of resources which encourages investment, consumption, trade and ultimately economic growth. On the other hand, empirical study done by Hsu, Tian and Xu (2011) has emphasized that developing the financial sector through innovation is essential to promote competition among financial institutions, and with more competition this would enhance the growth of the economy.

\subsection{Empirical Findings}

This sub section discusses empirical research applied in different countries to estimate the impacts of financial 
innovation on economic growth. In particular, the empirical research will be discussed based on different models and instrument used to measure economic development and financial innovation.

Hasan, Renzi, and Schmiedel (2013) estimated the relationship between retail payment (technological innovation) and the real economy using Generalized Methods of Moments (GMM) covering the period between 1995 and 2009 for $27 \mathrm{EU}$ countries. In their model, they measured technological innovation as the availability of ATMs and AFTPOS, while economic development is taken as GDP per capita, and they concluded that there is a positive relationship between economic development and technological innovation.

GMM was also used by Carbo, Paso, and Rodriguez (2004) to estimate the impacts of financial innovation on economic growth covering the period between 1986 and 2001 in 17 different regions in Spain. They used three different measures of economic development (GDP, Gross Fixed Capital Formation and Gross Savings) which were estimated simultaneously with respect to business innovation (mutual funds and loan commitments) and technological innovation (ATMs, debit and credit cards) as a measure of technological innovation. Their results showed that financial innovation has a positive influence on economic growth.

Djoumessi (2009) examined how the development of the financial sector affect the economic development in South Africa and Cameroon using Autoregressive Distributed Lag (ARDL) model and Vector Error Correction Model (VECM) between 1970 and 2006. In the study, economic development is measured as real GDP per capita while financial development was measured in three different ways, namely; ratio of broad money to GDP (M2/GDP), ratio of bank deposit to GDP and ratio of credit to private sector to GDP. The results showed that financial development influences economic development positively in Cameroon and South Africa when VECM was used, while ARDL model showed that financial development influences economic growth positively only in Cameroon.

Abdul Jalil and Ying Ma (2008) estimated the relationship between financial development and economic development using ARDL model for Pakistan and China covering the period between 1960 and 2005. They used ratio of deposit liabilities and credit to private sector as a measure of financial development and economic development as real GDP per capita. In this study, both measures of financial development has a positive relationship with economic growth in China, while in Pakistan only deposit liability ratio influences economic development positively.

\section{Data and Method of Analysis}

\subsection{Data}

The study uses quarterly time series data from the first quarter of 2006 to the fourth quarter of 2014 to estimate the role of financial development on economic growth in Botswana. We used real GDP as a measure of economic development and regressed it with respect to two types of financial development, business innovation (ratio of private sector credit to GDP and ratio of total deposit to GDP) and technological innovation (sum of units of EFTPOS and ATMs outlets), as well as major determinants of economic growth (ratio of trade to GDP, inflation rate and 3 month interest rate). The selection of these variables was guided by the ones used in empirical research reviewed. All the data were obtained from BoB's statistical reports (Bank of Botswana, 2000-2015).

\subsection{Model Specification}

The Autoregressive Distributed Lag (ARDL) model structure of Abdul Jalil and Ying Ma (2008) used to estimate the relationship between financial development and economic development in China and Pakistan is used in the analysis of this study as specified by equation 1. We used GDP as a measure of economic growth because GDP per capita which was predominately used in other studies (Hasan, Renzi, \& Schmiedel, 2013; Djoumessi, 2009; Abdul Jalil \& Ying Ma, 2008) was not available on quarterly basis. In addition, our measure of financial development differs from the one used by Abdul Jalil and Ying Ma (ratio of M2 to GDP). We separated financial development into business and technological innovation, which was adopted by Carbo, Paso and Rodriguez (2004).

The analytical framework which explores the relationship between economic growth and two types of financial development (technological and business innovation) as well as major determinants of economic growth is specified as:

$$
Y_{t}=a_{0}+a_{1} T I_{t}+a_{2} B I_{t}+a_{3} C P I_{t}+a_{4} R_{t}+a_{5} T R+a_{6} I_{t}+u_{t}
$$

where $Y_{t}$ is real GDP measuring economic development, Financial development is separated into technological 
innovation, $T I_{t}$ measured as the sum of ATMs and EFTPOS outlets) and business innovation, $B I_{t}$ measured as the ratio of credit to private sector to nominal GDP and ratio of total deposits to nominal GDP. We also use major determinants of economic growth including trade ratio, $T R_{t}$ measured as ratio of the sum of exports and imports to GDP, $I_{t}, 3$ month deposit interest rate, $R_{t}$ and inflation rate.

Equation 2 below is a representation of the ARDL model used to estimate the role of financial sector development on economic growth in Botswana. This model is chosen because the variables used in this study contains different order of integration as indicated by the co-integration test results in Table 3. Therefore, we preferred the ARDL model because it is suitable for a mixture of $\mathrm{I}(0)$ and $\mathrm{I}(1)$, and using it will help remove spurious results in our model.

$$
\begin{aligned}
& \Delta \log \left(Y_{t}\right)=\alpha_{0}+\delta_{1} \Delta \log \left(Y_{t-1}\right)+\lambda_{2} \Delta \log \left(T I_{t}\right)+\gamma_{3} \Delta \log \left(B I_{t}\right)+\phi_{4} \Delta \log \left(C P I_{t}\right) \\
& +\psi_{5} \Delta \log \left(R_{t}\right)+\varpi_{6} \Delta \log \left(T R_{t}\right)+\pi_{7} \Delta \log \left(I_{t}\right)+\beta_{1} \log \left(Y_{t-1}\right)+\beta_{2} \log \left(T I_{t-1}\right) \\
& +\beta_{3} \log \left(B I_{t}\right)+\beta_{4} \log \left(C P I_{t-1}\right)+\beta_{5} R_{t}+\beta_{6} \log \left(T R_{t-1}\right)+\beta_{7} \log \left(I_{t}\right) \\
& +\beta_{8} E C_{t-1}+\varepsilon_{t}
\end{aligned}
$$

$E C$ is error correction term used to capture the deviation of variables from long-run equilibrium, $\varepsilon_{t}$ is an error term assumed to be distributed with zero mean and constant variance, $\Delta$ denotes the differenced operator, and Greek letters are parameters to be estimated. The choice of our variables was guided by the ones used in empirical studies reviewed and we selected the ones which were statistically significant in our model.

Following economic theory, financial sector's technological innovation in the form of the availability of ATMs and EFTPOS is expected to have a positive impact on economic growth. Therefore, ATMs enhance economic growth through less operating costs due to less labor needed to assist customers at bank teller which improves banks performance. EFTPOS provide payments systems that are efficient in delivering bank services to customers and are cheaper when compared to cash payments, therefore, they facilitate household consumption, investment and trade leading to increased economic performance. On the business innovation side, credit to private sector is expected to have a positive impact on economic growth because it determines the quality of investment. Improvement in the level of credit to private sector will improve the quality and level of investment, and hence further improves economic growth because investment is one of the components of GDP. On the other hand, banks total deposits is also expected to have a positive impact on economic growth. The amount of deposits reflect the savings patterns and the amount of funds available for investment activities, and its improvement improves investment which further impact economic growth positively.

On the determinants of economic growth, international trade is expected to improve the performance of the economy. Since the economy of Botswana is more dependent on trade, more specifically diamond exports, improvements in trade would have a positive and significant impact in the growth of the economy. Interest rate is expected to have a negative relationship with economic growth. Therefore, because of the forgone interest that could have been earned by depositing money in more interest earning assets instead of spending it in the consumption of goods and services, individuals are expected to consume less with an increase in interest rate.

The expected impact of inflation on economic growth is ambiguous. From the demand-supply theory, an increase in the amount of goods and services produced nationally (measuring GDP) is expected to ease inflationary pressure, assuming demand stays unchanged, suggesting a negative relationship between inflation and economic growth. On the other hand, countries with increased economic growth expect its residents to demand an increases in wages and salaries, as a results, cost of production for producers will increase due to salary increments. Therefore, producers will increase the price of their product to cope with the high costs of production, which would lead to an increase in inflation, suggesting positive relationship between inflation and economic growth. Therefore, the sign for inflation would depend on which of the two effects dominates.

\section{Estimated Results and Discussion}

\subsection{Unit Root Test}

Prior to model estimation, all the variables used in this study were tested for their time series properties using Phillips-Perron (PP) test in order to determine the presence of unit root. The result are presented in Appendix, Table E1, show that after first differencing, the null hypothesis of no unit root in the series cannot be rejected for all the variables at 1 percent level of significance, except the 3 month interest rate which was stationary at 5 percent without being differenced. The results indicate that these variables are $\mathrm{I}(1)$ while interest rate is $\mathrm{I}(0)$, 
which implies that the I(1) variable need to be transformed into stationary data by applying natural logarithm before they can be used for estimation.

\subsection{Cointegration Test}

Since the variables used have the different order of integration, $\mathrm{I}(0)$ and $\mathrm{I}(1)$ variables, Johansen Cointegration test was performed in order to establish the existence of long run relationship among them. For at least one long-run relationship to be evident among the variables, Trace test statistics or Maximal Eigen value has to be less than their respective critical values. The results of cointegration test are presented in Table 3.

Both the Trace test statistics and Maximal Eigen Value indicate 1 long run relationship among the variables. Therefore, we chose ARDL model because is suitable for non-stationary data with different order of integration as well as having one cointegrating vector (long-run relationship).

Table 3. Johansen cointegration test

\begin{tabular}{lcccc}
\hline $\begin{array}{l}\text { Hypothesized } \\
\text { No. of CE(s) }\end{array}$ & $\begin{array}{c}\text { Trace } \\
\text { Statistics }\end{array}$ & $\begin{array}{c}\text { Critical Value } \\
\text { @ 5\% }\end{array}$ & $\begin{array}{c}\text { Maximal } \\
\text { Eigen Value }\end{array}$ & $\begin{array}{c}\text { Critical Value } \\
\text { @ 5\% }\end{array}$ \\
\hline None & 86.8 & 69.8 & 35.6 & 33.9 \\
At most 1 & 51.2 & 47.9 & 22.6 & 27.6 \\
At most 2 & 28.5 & 29.8 & 20.4 & 21.1 \\
At most 3 & 8.17 & 15.5 & 6.37 & 14.3 \\
At most 4 & 1.80 & 3.84 & 1.80 & 3.84 \\
\hline
\end{tabular}

\subsection{Estimates of an ARDL Model}

The results of the ARDL model used to estimate the role of financial development on economic growth together with other determinants of economic development are represented in Table 4 (Long Run estimates) and Table 5 (Short Run estimates), estimated using equation 2.

All the variables included in our model are statistically significant with theoretically expected signs. Both in the long-run and short-run, international trade and 3 months deposit interest rate are positively and negatively related to economic growth, respectively, and are significant at five percent level of significance. This shows that an increase in trade would lead to an increased economic growth. The negative relationship of interest rate with economic growth is in line with theoretical expectation. It indicates that an increase in interest rate would motivate households to invest in more interest earning assets and lower their current spending and hence slower economic growth. The long-run and short-run coefficients for inflation have a negative impact on economic growth and are significant at one percent level of significance. It shows that an ease in inflationary pressures encourage the public to spend more on goods and services which increases consumption. High level of consumption as a component of GDP will also facilitate economic growth.

Table 4. Long run estimates

\begin{tabular}{lccc}
\hline Variable & Coefficient & T-Statistic & P-Value \\
\hline Constant & 5.78 & 9.21 & 0.000 \\
GDP & 0.35 & 5.51 & 0.000 \\
Inflation & -0.08 & -2.63 & 0.017 \\
Trade & 0.29 & 5.43 & 0.000 \\
Private Sector Credit & 0.18 & 4.57 & 0.000 \\
Total Deposits & 0.14 & 6.24 & 0.000 \\
ATMs and EFTPOS & 0.09 & 2.21 & 0.040 \\
Interest Rate & -0.04 & -1.99 & 0.002 \\
\hline R-Squared & 0.97 & DW Statistic & 2.154 \\
Adjusted R-Squared & 0.96 & Prob (F-test) & 0.000 \\
\hline
\end{tabular}


Table 5. Short run estimates

\begin{tabular}{lccc}
\hline Variable & Coefficient & T-Statistic & P-Value \\
\hline Constant & 0.07 & 1.51 & 0.14 \\
GDP & 0.27 & 2.67 & 0.017 \\
Inflation & -0.07 & -3.39 & 0.003 \\
Trade & 0.16 & 1.88 & 0.039 \\
Private Sector Credit & 0.06 & 2.61 & 0.019 \\
Total Deposits & 0.08 & 7.14 & 0.000 \\
ATMs and EFTPOS & 0.05 & 2.83 & 0.012 \\
Interest Rate & -0.03 & -3.69 & 0.002 \\
ECM & -0.57 & -5.58 & 0.000 \\
\hline R-Squared & 0.89 & DW Statistic & 1.97 \\
Adjusted R-Squared & 0.83 & Prob (F-test) & 0.000 \\
\hline
\end{tabular}

Regarding innovation indicators, the coefficient for technological innovation variable measured as the sum of ATMs and EFTPOS outlets is significant at one percent both in the long-run and short-run, and has a positive impact on economic growth. This reflects that as the number of EFTPOS outlets increases, this avail more alternative system of payments that are efficient and less costly when compared to cash payments, and hence facilitate payments of goods for consumption, investment and trade which improves economic growth. On the other hand, increasing number of ATMs also encourages economic growth through promoting bank productivity and performance by reducing the their labor costs hence less manpower will be needed to assist customer at bank tellers.

The coefficient for credit to the private sector has a positive impact on the growth of the economy both in the long-run and short run, and is significant at one percent level of significance. Increase in the level of credit provided to the private sector encourages increased level and quality of investment leading to increased economic growth. The coefficient for total deposit also has a positive impact on economic growth and is significant at one percent level of significance. As total deposit increases, this avails more funds for future investment and thus increasing economic growth in the long run. The coefficient for error correction term is significant with negative expected sign (-0.57), indicating that more than 57 percent of errors in the short run are corrected back to its equilibrium in the long run.

To determine the robustness of our results, we checked basic performance indicators. The estimated model yielded high values of R-squared and adjusted R-squared which indicate that the sample data fitted our model reasonably well. We also performed a couple of diagnostic tests to further check the strength of our model, the results presented in Table E2 in Appendix. The presence of both serial correlation and heteroskedasticity were not detected in our model. In addition, Ramsey Reset test shows that the model is correctly specified, while the Jarque-Bera Normality test shows that residuals are normally distributed.

\section{Concluding Remarks and Policy Implications}

The objective of this study was to examine the role of financial sector innovation on economic growth. The study established that financial sector development, more particularly technological innovation promotes increased performance of the financial sector through: providing cost effective and efficient payment systems; reduce bank's labor costs which would lead to improvement in productivity and efficiency of financial institutions; increase consumption and trade of goods and services; and increase funds for investment opportunities.

Despite the progress made, development of Botswana's financial sector is still behind and not competitive when compared to other countries around the world. It was ranked 53 by both the 2012/13 and 2013/14 GCR in terms of financial market development. In terms of technological readiness, it was ranked 106 and 104 by the 2012/13 and 2013/14 GCR, respectively. The financial sector's inability to be competitive is due to lack of the soundness of the banking sector, limited availability of the latest technology, lack of capacity for innovation and limited financial services availed to the public. The 2013/14 GCR ranked Botswana 46, 91, 102, and 78 in terms of soundness of banks, availability of latest technology, capacity for innovation and availability of financial services, respectively. The main factor identified for dragging the competitiveness of the financial sector down is the quality of the education system, which is focused moreon academic achievement rather than providing learners with practical skills needed in the labor market. Its quality of the education system was ranked 58, 55 and 65 by the 2011/12,2012/13 and 2013/14 GCR, respectively. 
An Autoregressive Distributed Lag (ARDL) model was used to estimate the role of financial development on economic growth using quarterly data from 2006 to 2014. We used two types of financial development, technological innovation (sum of ATMs and EFTPOS) and business innovation (shares of deposits and credit to private sector to GDP) as well as major determinants of economic growth (trade, inflation and interest rate). The coefficients for all the variables used were statistically significant with expected signs. In the long-run, a percentage change in the lagged value of real GDP, inflation, trade, credit to private sector, total deposits, sum of ATMs and EFTPOS outlets and 3 months deposit interest rate would lead to 0.35, -0.08, 0.29, 0.18, 0.14, 0.09, and -0.04 percentage change in economic growth, respectively.

The technological and business innovation variables have a positive impact on economic growth. Therefore, more availability of ATMs would reduce financial sector labor costs, thereby, improving the productivity and performance of financial institutions. In addition, more availability of EFTPOS would provide payments system that are efficient and cost effective when compared to cash payments, thereby facilitate more consumption of goods and services, more spending on investment goods and easy payments of tradable goods and services which as a result would lead to increased growth of the economy. Therefore, policies aimed at promoting business innovation as well as technological innovation (more installation of EFTPOS and ATMs outlets) more particularly in rural areas where they are scarce will offer a much needed boost to improve the productivity and performance of the financial sector. However, for the business and technological innovation to significantly boost the performance of the financial sector, the education system in Botswana need to be restructured in order to enable it to provide learners with practical skills needed in the labor market that can help to support the national innovative initiatives.

\section{Acknowledgements}

I am thankful to Dr Grace Tabengwa of Botswana Institute for Development Policy Analysis for contributing for suggestion on the structure of the paper. Without her contribution I would have find it difficult to finish this paper.

\section{References}

Abdul, J., \& Ying, M. (2008). Financial Development and Economic Growth: Time Series Evidence from Pakistan and China. Journal of Economic Cooperation, 29(2), 29-68.

Bank of Botswana Annual Report. (2000-2012). Gaborone, Botswana.

Carbo-Valverde, S., Paso, R. L., \& Rodriguez-Fernandez, F. (2004). Financial Innovation in Banking: Impact on Regional Growth. University of Granada, Department of Economics, Spain.

Djoumessi, E. C. K. (2009). Financial Development and Economic Growth: A Comparative Study between Cameroon and South Africa. Masters of Commerce Dissertation, University of South Africa, Department of Economic.

Hasan, I., Renzis, T. D., \& Schmiedel, H. (2012). Retail Payments and Economic Growth. Bank of Finland, Research Discussion Paper 19. http://dx.doi.org/10.2139/ssrn.2100651

Hasan, I., Renzis, T. D., \& Schmiedel, H. (2013). Retail Payments and Real Economy. European Central Bank, Working Paper Series No. 1572.

Ho, N. W. (2006). Financial Innovation and its Impacts on Central Bank Policies. Monetary Authorities of Macao.

Hsu, P., Tian, X., \& Xu, Y. (2011). Financial Development and Innovation: Cross-Country Evidence. University of Hung Kong, Faculty of Business and Economics, Indiana University, Kelly School of Business and University of Rhode Island, College of Business Administration.

Kumaga, D. (2010). The Challenges of Implementing Electronic Payments Systems-The Case of Ghana's E-zwich Payment System. School of Management, Master's Thesis in Business Administration.

Markose, S. M., \& Loke, Y. J. (2003). Network Effects on Cash-Card Substitution in Transition and Low Interest Rate Regimes. Economic Journal, 113, 456-476. http://dx.doi.org/10.1111/1468-0297.00124

Ogbuji, C. N., Onuoha, C. B., \& Izogo, E. E. (2012). Analysis of the Negative Effects of the Automated Teller Machine as a Channel for Delivering Bank Services in Nigeria. International Journal of Business and Management, 7(7). http://dx.doi.org/10.5539/ijbm.v7n7p180

World Economic Forum. (2009/10). The Global Competitiveness Report. World Economic Forum, Geneva, Switzerland. 
World Economic Forum. (2010/11). The Global Competitiveness Report, World Economic Forum, Geneva, Switzerland.

World Economic Forum. (2011/12). The Global Competitiveness Report, World Economic Forum, Geneva, Switzerland.

World Economic Forum. (2012/13). The Global Competitiveness Report, World Economic Forum, Geneva, Switzerland.

World Economic Forum. (2013/14). The Global Competitiveness Report, World Economic Forum, Geneva, Switzerland.

\section{Appendix}

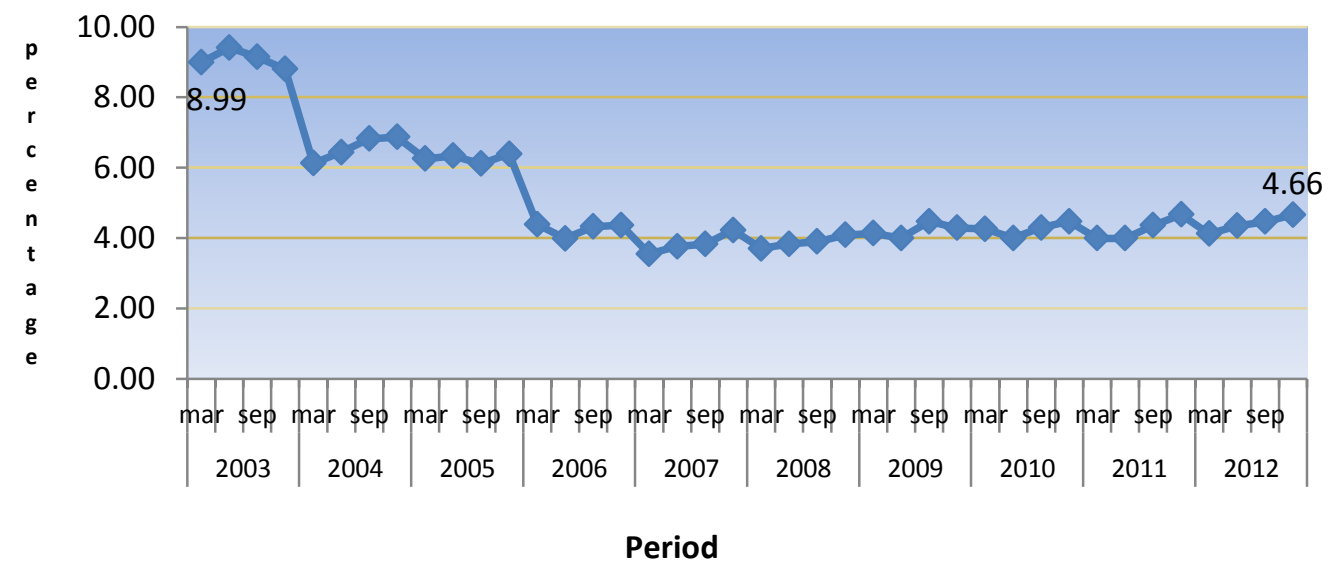

Figure E1. Currency in Circulation as a percentage of M2

Table E1. Unit root test

\begin{tabular}{lcccc}
\hline Variable name & ADF test & CV @ 1\% & CV @ 5\% & Integration order \\
\hline Real GDP* & -5.42 & -2.66 & -1.95 & 1 \\
Private Spending* & -5.19 & -2.66 & -1.95 & 1 \\
3 month interest rate & -5.27 & -2.66 & -1.95 & 0 \\
EFTPOS transaction* & -4.78 & -2.66 & -1.95 & 1 \\
ATMs transaction* & -4.90 & -2.66 & -1.95 & 1 \\
\hline
\end{tabular}

Note. * indicate the variable being first differenced.

CV denotes critical values.

Table E2. Diagnostic tests

\begin{tabular}{lcccc}
\hline Diagnostic test & P-value (P) & Significance (S) & Decision Rule & Conclusion \\
\hline $\begin{array}{l}\text { LM Serial Correlation } \\
\text { H0: No serial correlation }\end{array}$ & 0.09 & $@ 1 \%=0.01$ & $\begin{array}{c}\text { Reject } \mathrm{H} 0 \\
\text { if } \mathrm{P}<\mathrm{S}\end{array}$ & Cannot reject H0 \\
$\begin{array}{l}\text { Ramsey Reset Test } \\
\text { H0: Model is correctly specified }\end{array}$ & 0.88 & $@ 1 \%=0.01$ & $\begin{array}{c}\text { Reject } \mathrm{H} 0 \\
\text { if } \mathrm{P}<\mathrm{S}\end{array}$ & Cannot reject H0 \\
$\begin{array}{l}\text { Heteroskedasticity Test } \\
\text { H0: Homoskedasticity }\end{array}$ & 0.37 & $@ 1 \%=0.01$ & $\begin{array}{c}\text { Reject H0 } \\
\text { if } \mathrm{P}<\mathrm{S}\end{array}$ & Cannot reject H0 \\
$\begin{array}{l}\text { Normality Test } \\
\text { H0: Residuals are normally distributed }\end{array}$ & 0.63 & $@ 1 \%=0.01$ & $\begin{array}{c}\text { Reject } \mathrm{H} 0 \\
\text { if } \mathrm{P}<\mathrm{S}\end{array}$ & Cannot reject H0 \\
\hline
\end{tabular}




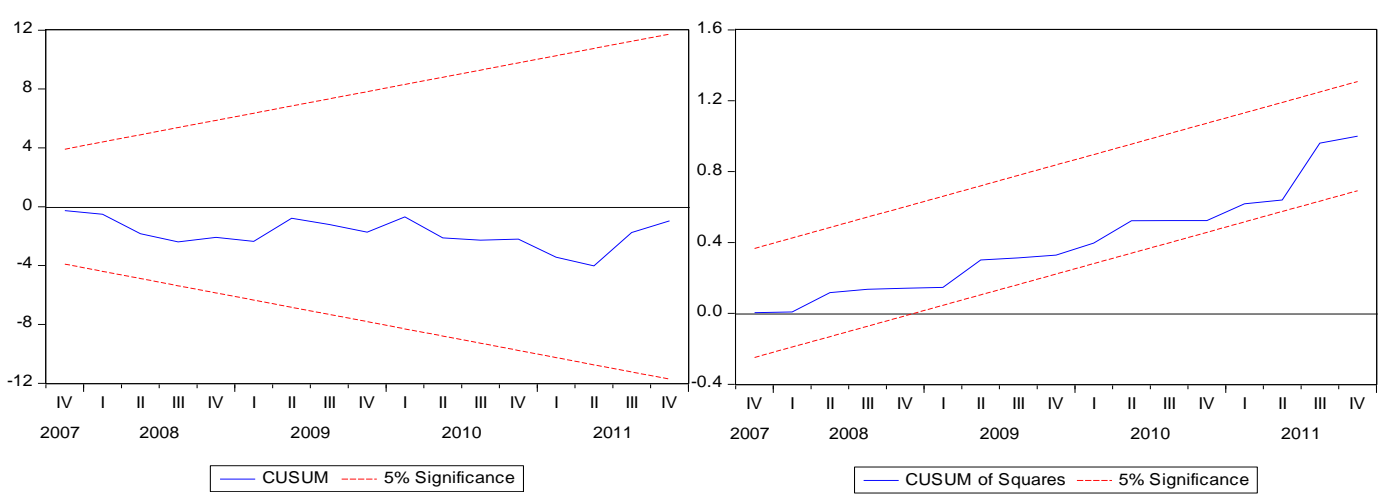

Figure E2. Stability test

Note. Residuals (blue line) which cross the two red dotted lines (standard error bands) indicate the instability in the coefficient of the estimated model.

\section{Copyrights}

Copyright for this article is retained by the author(s), with first publication rights granted to the journal.

This is an open-access article distributed under the terms and conditions of the Creative Commons Attribution license (http://creativecommons.org/licenses/by/3.0/). 